\title{
Quality of life of nurses
}

\author{
Sandra Joković, Maja Račić, Jelena Pavlović, Natalija Hadživuković \\ University of East Sarajevo, Faculty of Medicine Foca, \\ Osmana Bikića bb, Foca, Bosnia and Herzegovina \\ sandra.jokovic@hotmail.com; porodicnamedicina@gmail.com; \\ pjelena551@gmail.com; natalijahadživukovic@yahoo.com
}

\begin{abstract}
Introduction: In modern medical practice, the concept of quality of life has recently gained a great significance and important role in problem analysis in a variety of clinical situations. The aim of this study has been to assess the level of perceived quality of life of nurses. Methodology: The study was designed as a cross-sectional study. The sample of the study consisted of nurses in primary and secondary health care. A sociodemographic questionnaire and questionnaire of health assessment (SF-36) were used for assessment of quality of life. Statistical analysis was done using the SPSSver. 20.o. Results: The highest percentage of respondents $(67 \%)$ belong to the category of excellent physical functioning. Thirty percent belong to the group that has good physical functioning, whereas only $3 \%$ of the subjects have poor physical performance. Fifty-two percent of respondents have excellent social functioning, $47 \%$ have a good level of performance, while only two patients have a poor level of social functioning. Thirty percent of respondents have significant limitations due to emotional problems. Disscusion and conclusion: Sociodemographic characteristics significantly affect the quality of life of nurses

Key words: quality of life, health, nurses
\end{abstract}

I

$\mathrm{n}$ recent years there has been a great interest in exploring the psychosocial aspects of the work environment of health workers. The reasons for this are the poor financial status, insufficient physical security, working in night shifts, as well as poor working conditions with great physical and mental load (Assalavi et al., 2010; Milošević et al., 2011).Working in nursing job it constantly involves dealing with human needs, problems and suffering, constant interaction with co-workers, clients and their families, as well as different organizational burden (Golubić and Mustajbegović, 2011). 
Numerous studies conducted in different countries of the world have shown that the prevalence of work-related stress among nurses is high (Chapman et al., 2010; Iliopoulou and While, 2010; Habazin, 2013). Out of the above mentioned pathological conditions most often singled out are emotional exhaustion, chronic fatigue, cardiovascular diseases, tumors, and pain in the lower part of the spine (Golubić and Mustajbegović, 2011; Milošević et al., 2011). The workplace and the type of work they do is also an important factor that affects the quality of life and job satisfaction of nurses. A prerequisite for security and satisfaction of a nurse in the workplace is certainly working environment which meets the expected safety standards, ensures the prevention of injuries and diseases that can occur during the working process, and therefore ensures the presence of healthy nurses, unencumbered by working conditions (Spurgeon, et al., 1997; Jezuit, 2003). Nursing profession because of the patient care that takes place continuously for 24 hours, including work in rotating night shifts, has a significant impact on various aspects of their lives. The system of rotating night shifts is often associated with sleep disorders that can damage their physical health by increasing the rate of cardiovascular, gastrointestinal and cancer. Also, working rotating night shifts can negatively affect the mental functioning and reduce the concentration which increases the risk of errors in work (Cimete et al., 2003; Lie et al., 2006; Shao, et al., 2010). Great emotional and physical efforts and insufficient rewards are topics that are high at the priority list of the nursing profession (Golubić and Mustajbegović, 2011). Therefore, we can say that the quality of life of nurses is a complex entity being under the influence of and interacting with many aspects of their work environment and personal lives outside of them. The aim of this study was to assess the level of perceived quality of life of nurses, as well as to estimate the differences in the quality of life of nurses depending on their the place of work (Assalavi et al., 2010; Golubić and Mustajbegović, 2011).

\section{Methods}

The study was designed as a cross-sectional study. The study involved 200 nurses working in primary and secondary health care. Criteria for inclusion in the study were: respondents who work at least one year and are directly involved in the care and treatment of patients. Criteria for exclusion from the study were: respondents who work less than one year, nursing who are not involved in the care and treatment of patients and subjects who did not respond to five or more questions or have circled the same answers to all the questions. The research was conducted at the University Hospital Foca, Health CenterZvornik and Health Center of East Sarajevo. The survey used: a sociodemographic questionnaire, and a questionnaire to assess the health status (Short Form-36 Health Survey SF-36) (Ware et al., 1993; 2000). The socio-demographic questionnaire designed for this study and contains 14 questions relating to the characteristics of the respondents (gender, age, marital status, place of residence, family income, education level of respondents). 
SF-36 Health Survey is the most commonly used general questionnaire to assess quality of life of patients. The questionnaire is designed for self-assessment of mental and physical health, and social functioning. There are 36 questions, of which 35 questions grouped into eight areas:

1. PF-physical functioning - 10 items,

2. RP - role limitation due to emotional problems - 4items,

3. RE- rolls limitation due to emotional problems -3 items,

4. SF- social functioning) -2 items,

5. $\mathrm{MH}$ mental health -5 items ,

6. The vitality and energy -4 items,

7. BP bodily pain -2 items,

8. GH general health perception -5 items.

One question related to the change of health status in relation to the year preceding the survey, ie. whether the current health is better, the same or worse. For each of the eight domains of the total score ranges from o to 100 points (percent), wherein o is a very low quality of life associated with that domain 100, and is a very positive response and a high level of quality of life. In our study we used linguistic versions of validated questionnaires, translated into Serbian. Statistical analysis was performed using SPSS ver. 20.0. The chuare test was applied. As the level of statistical significance of differences, $\mathrm{p}<0.05$, werw calculed by using the arithmetic mean and standard deviation.

\section{Results}

The following tables (Table 1-4) are presenting the results of the research.

Table 1: Distribution of respondents according to gender and age.

\begin{tabular}{|c|c|c|c|c|c|}
\hline \multirow{2}{*}{$\begin{array}{l}\text { Gender of } \\
\text { respondents }\end{array}$} & \multicolumn{2}{|c|}{ Age of respondents $n$ (\%) } & \multirow{2}{*}{ Total $n(\%)$} & \multirow{2}{*}{$\chi^{2}$} & \multirow{2}{*}{$p$} \\
\hline & $20-39$ years & $40-60$ years & & & \\
\hline Men & $26(13)$ & $11(5.5)$ & $37(18.5)$ & \multirow{3}{*}{17,987} & \multirow{3}{*}{0,001} \\
\hline Women & $53(26.5)$ & $110(55)$ & $67(67)$ & & \\
\hline $\begin{array}{l}\text { Total } \\
\mathrm{n}(\%)\end{array}$ & $79(39.5)$ & $121(60.5)$ & $100(100)$ & & \\
\hline
\end{tabular}


Table 2: Distribution of respondents according to socio-demographic characteristics.

\begin{tabular}{|c|c|c|c|c|c|c|}
\hline \multirow{2}{*}{$\begin{array}{l}\text { Socio-demographic } \\
\text { characteristics }\end{array}$} & \multirow{2}{*}{ Possible answers } & \multicolumn{2}{|c|}{$\begin{array}{c}\text { Respondents place of work } \\
n(\%)\end{array}$} & \multirow{2}{*}{ Total $n(\%)$} & \multirow{2}{*}{$\chi^{2}$} & \multirow{2}{*}{$p$} \\
\hline & & Primary care & $\begin{array}{l}\text { Secondary } \\
\text { care }\end{array}$ & & & \\
\hline \multirow{4}{*}{ Marriage } & Married & $61(30.5)$ & $66(33)$ & $127(63,5)$ & \multirow{4}{*}{1.737} & \multirow{4}{*}{0.629} \\
\hline & Not married & $17(8.5)$ & $19(9,5)$ & $36(18)$ & & \\
\hline & Divorced & $12(6)$ & $9(4.5)$ & $21(10.5)$ & & \\
\hline & Widow/Widower & $10(5)$ & $6(3)$ & $16(8)$ & & \\
\hline \multirow[b]{2}{*}{ Place of living } & Urban & $32(16)$ & $12(6)$ & $44(22)$ & \multirow[b]{2}{*}{11.65} & \multirow[b]{2}{*}{0.001} \\
\hline & Rural & $68(34)$ & $88(44)$ & $156(78)$ & & \\
\hline \multirow{2}{*}{$\begin{array}{l}\text { Educational back- } \\
\text { ground }\end{array}$} & Secondary school & $83(41.5)$ & $87(43.5)$ & $170(85)$ & \multirow{2}{*}{5.022} & \multirow{2}{*}{0.081} \\
\hline & College & $17(8.5)$ & $13(6.5)$ & $30(15)$ & & \\
\hline \multirow{3}{*}{ Work experience } & $1-10$ years & $30(15)$ & $37(18.5)$ & $67(33.5)$ & \multirow{3}{*}{11.678} & \multirow{3}{*}{0.432} \\
\hline & $11-25$ years & $17(8.5)$ & $19(9.5)$ & $36(18)$ & & \\
\hline & $26-40$ years & $53(26.5)$ & $44(22)$ & $97(48,5)$ & & \\
\hline \multirow{2}{*}{ Working in shifts } & Yes & $51(25.5)$ & $77(38.5)$ & $128(64)$ & \multirow{2}{*}{14.670} & \multirow{2}{*}{0.023} \\
\hline & No & $49(24.5)$ & $23(11.5)$ & $72(36)$ & & \\
\hline \multirow{2}{*}{ Educative lectures } & Yes & $70(35)$ & $80(40)$ & $150(75)$ & \multirow{2}{*}{2.667} & \multirow{2}{*}{0.102} \\
\hline & No & $30(15)$ & $20(10)$ & $50(25)$ & & \\
\hline
\end{tabular}


Table 3: The level of quality of life in the three subscales of the SF-36: physical functioning, the existence of bodily pain and vitality in nurses and technicians who work in primary and secondary health care.

\begin{tabular}{|c|c|c|c|c|c|c|}
\hline \multirow{2}{*}{$\begin{array}{l}\text { Domains of the } \\
\text { SF-36 question- } \\
\text { naire }\end{array}$} & \multirow[b]{2}{*}{$\begin{array}{l}\text { The level of } \\
\text { quality of life }\end{array}$} & \multicolumn{2}{|c|}{ Respondents place of work } & \multirow[b]{2}{*}{ Total $n(\%)$} & \multirow[b]{2}{*}{$\chi^{2}$} & \multirow[b]{2}{*}{$p$} \\
\hline & & $\begin{array}{c}\text { Primary care, } \\
n(\%)\end{array}$ & $\begin{array}{c}\text { Secondary care, } \\
n(\%)\end{array}$ & & & \\
\hline \multirow{3}{*}{$\begin{array}{l}\text { Physical func- } \\
\text { tioning }\end{array}$} & $\begin{array}{l}\text { Bad } \\
(0-33 \%) \\
\end{array}$ & $2(1)$ & $4(2)$ & $6(3)$ & \multirow{3}{*}{9.751} & \multirow{3}{*}{0.008} \\
\hline & $\begin{array}{l}\text { Good } \\
(33-66 \%)\end{array}$ & $40(20)$ & $20(10)$ & $60(30)$ & & \\
\hline & $\begin{array}{l}\text { Excellent } \\
(66-100 \%)\end{array}$ & $58(29)$ & $76(38)$ & $134(67)$ & & \\
\hline \multirow{3}{*}{$\begin{array}{l}\text { The existence of } \\
\text { physical pain }\end{array}$} & $\begin{array}{l}\text { Intense } \\
(\mathrm{o}-33 \%) \\
\end{array}$ & $8(4)$ & $4(2)$ & $12(6)$ & \multirow{3}{*}{3.567} & \multirow{3}{*}{0.168} \\
\hline & $\begin{array}{l}\text { Moderate } \\
(33-66 \%) \\
\end{array}$ & $32(16)$ & $24(12)$ & $56(28)$ & & \\
\hline & $\begin{array}{l}\text { Does not exist } \\
(66-100 \%)\end{array}$ & $60(30)$ & $72(36)$ & $132(66)$ & & \\
\hline \multirow{3}{*}{ Vitality } & $\begin{array}{l}\text { Bad } \\
(\mathrm{o}-33 \%) \\
\end{array}$ & $2(1)$ & $8(4)$ & $10(5)$ & \multirow{3}{*}{3.834} & \multirow{3}{*}{0.147} \\
\hline & $\begin{array}{l}\text { Good } \\
(33-66 \%) \\
\end{array}$ & $80(40)$ & $74(37)$ & $154(77)$ & & \\
\hline & $\begin{array}{l}\text { Excellent } \\
(66-100 \%)\end{array}$ & 18 (9) & 18 (9) & $36(18)$ & & \\
\hline
\end{tabular}

Table 4: The level of quality of life in the three subscales of the SF-36: social functioning, the existence of limitations due to emotional problems and mental health among nurses and technicians working in primary and secondary health care

\begin{tabular}{|c|c|c|c|c|c|c|}
\hline \multirow{2}{*}{$\begin{array}{l}\text { Domains of the } \\
\text { SF-36 question- } \\
\text { naire }\end{array}$} & \multirow{2}{*}{$\begin{array}{l}\text { The level of } \\
\text { quality of life }\end{array}$} & \multicolumn{2}{|c|}{ Respondents place of work } & \multirow[b]{2}{*}{ Total n (\%) } & \multirow[b]{2}{*}{$\chi^{2}$} & \multirow[b]{2}{*}{$p$} \\
\hline & & $\begin{array}{c}\text { Primary care, } \\
n(\%)\end{array}$ & $\begin{array}{c}\text { Secondary care, } \\
n(\%)\end{array}$ & & & \\
\hline \multirow{3}{*}{$\begin{array}{l}\text { Social } \\
\text { functioning }\end{array}$} & $\begin{array}{l}\text { Bad } \\
(\mathrm{o}-33 \%)\end{array}$ & I & $2(1)$ & $2(1)$ & \multirow{3}{*}{4.448} & \multirow{3}{*}{0.108} \\
\hline & $\begin{array}{l}\text { Good } \\
(33-66 \%) \\
\end{array}$ & $42(21)$ & $52(26)$ & $94(47)$ & & \\
\hline & $\begin{array}{l}\text { Excellent } \\
(66-100 \%)\end{array}$ & $58(29)$ & $46(23)$ & $104(52)$ & & \\
\hline \multirow{3}{*}{$\begin{array}{l}\text { The limitation } \\
\text { due to emotional } \\
\text { problems }\end{array}$} & $\begin{array}{l}\text { Intense } \\
(\mathrm{o}-33 \%)\end{array}$ & $38(19)$ & $22(11)$ & $60(30)$ & \multirow{3}{*}{11.590} & \multirow{3}{*}{0.003} \\
\hline & $\begin{array}{l}\text { Moderate } \\
(33-66 \%) \\
\end{array}$ & $8(4)$ & $2(1)$ & $10(5)$ & & \\
\hline & $\begin{array}{l}\text { Does not exist } \\
(66-100 \%)\end{array}$ & $54(27)$ & $76(38)$ & $130(65)$ & & \\
\hline
\end{tabular}




\begin{tabular}{|c|c|c|c|c|c|c|}
\hline \multirow{2}{*}{$\begin{array}{c}\text { Domains of the } \\
\text { SF-36 question- } \\
\text { naire }\end{array}$} & \multirow{2}{*}{$\begin{array}{l}\text { The level of } \\
\text { quality of life }\end{array}$} & \multicolumn{2}{|c|}{ Respondents place of work } & \multirow{2}{*}{ Total n (\%) } & \multirow[b]{2}{*}{$\chi^{2}$} & \multirow[b]{2}{*}{$p$} \\
\hline & & $\begin{array}{c}\text { Primary care, } \\
n(\%)\end{array}$ & $\begin{array}{c}\text { Secondary care, } \\
n(\%)\end{array}$ & & & \\
\hline \multirow{3}{*}{ Mental health } & $\begin{array}{l}\text { Bad } \\
(\mathrm{o}-33 \%)\end{array}$ & I & $4(2)$ & $4(2)$ & \multirow{3}{*}{8.138} & \multirow{3}{*}{0.017} \\
\hline & $\begin{array}{l}\text { Good } \\
(33-66 \%) \\
\end{array}$ & $98(49)$ & $88(44)$ & $186(93)$ & & \\
\hline & $\begin{array}{l}\text { Excellent } \\
(66-100 \%)\end{array}$ & $2(1)$ & $8(4)$ & $10(5)$ & & \\
\hline
\end{tabular}

\section{Discussion}

In our research, out of nurses of both levels of health care, the best quality of health had the following domains: physical functioning, absence of bodily pain, social functioning, limitations due to physical health problems and limitations due to emotional problems. The lower level of quality of the health of our patients is seen in median values of public health, mental health and vitality.

The largest percentage of our respondents, $67 \%$ belong to the category of excellent physical functioning, $30 \%$ have a good physical functioning, while only $3 \%$ of respondents have a poor physical functioning. Among the respondents in relation to the place of work was observed statistically significant differences in terms of physical functioning, with respondents who work in secondary care showed better physical functioning. In contrast to our research, in a study conducted in Taiwan on a sample of 1534 nurses, the results showed that nurses who work in outpatient clinics have better physical functioning compared to nurses working in hospital wards and intensive care units (Shao et al, 2010). Similar results were obtained in studies in Turkey, where the nurses who worked in an outpatient clinics have a better quality of life in relation to nursing working in a surgical departments and operating rooms (Cimete et al, 2003). The limitations due to emotional problems are present in $30 \%$ of our respondents, moderate limitations has $5 \%$ of respondents, while in slightly more than half of the respondents limitations due to emotional problems do not exist. In relation to the place of work statistically significant difference was observed, with limitations due to emotional problems more common among respondents who work in primary health care. Experiencing positive emotions at work is considered an important part of nursing professional life, and has a significant impact on patient safety, quality of services renered, commitment, retention and fluctuation. Many studies alsoconfirmed this fact and point out that experiencing positive emotions at work linked with better health, a higher degree of job satisfaction, responsible behavior at work, higher work performance and quality of work, greater resistance to stress and burnout, rarely change jobs, better relations with other persons, the preferred behavior and thinking, and lower incidence of divorce (Chapman et al., 2010; Golubić and Mustajbegović, 2011; Habazin, 2013). 
High proportion of respondents assessed their mental health as good:Excellent mental health has $4 \%$ of secondary and $1 \%$ of primary health care, and poor mental health has $2 \%$ of the respondents belonging to secondary health care, while in the primary with poor mental health was not. Next results longitudinal study of 11 countries showed that in all countries there is a significant degree of psychological exhaustion of nursing personnel, in particular in Poland, Slovakia and Germany where they registered the highest scores adverse effects (Cowin, 2002). As regards the existence of pain and vitality of our respondents, it was found that almost two-thirds of our respondents, there is no pain in everyday life, in $28 \%$ of the pain there and he is moderate, and $6 \%$ of the pain is very strong. Our subjects have the highest percentage of vitality, $18 \%$ of the subjects is excellent vitality when in the smallest percentage of the sample is poor viability, wherein between the two groups of subjects in relation to the place of work, no significant difference in terms of the existence of pain, and in terms of vitality. Similar results were obtained in a study conducted by Hasselhorm et al.(2005) with the nurses in Germany. The disease is undoubtedly one of the external factors that negatively affect the quality of life of the individual. It can be said that the impact of disease on quality of life is multidimensional. The disease not only in terms of affecting the physical symptoms, and thus hinders the functioning, but there are present and indirect effects such as a change in working ability, the decline in the quality of medical care, the potential isolation, the increase depending on the other, bad habits,etc. (Knežević et al., 2009; Buljbašić, 2011). Respondents on both levels of health care have the highest percentage of good and excellent social functioning, while only two patients from secondary care have poor levels of social functioning. Studies dealing with the study of the quality of life highlight the importance of social contacts, and there is a large drop in the quality of life in patients where there is social isolation. Certain contribution to the clarification of the impact of social interaction on the quality of life given by Israeli researchers, who have studied only that component of health and its impact on quality of life (William et al., 1996).

\section{Conclusions}

Respondents expressed the best quality of health in physical functioning, absence of bodily pain and social functioning. The lower level of quality of health of our respondents was noticed in the fields of public health, mental health and vitality. Nurses from primary health care, when compared with their colleagues from secondary care, assessed their mental health better. On the other hand, nurses from secondary health care expressed better quality of health in physical functioning and limitations due to emotional problems.

\section{References}

ASSALAVI, R.K., APERECIDA, B.D., and GONCALVES, S.B.A., 2010. Evaluation of quality of life and depression in nursing technicians and nursing assistants. Rev. Latino-Am Enfermagem, vol. 18, iss. 3, pp. 413-420. 
BULJAŠIĆ A., 2011. Zastupljenost i utjecaj mobinga na radne aktivnosti medicinskih sestara. HČJZ.

CHAPMAN, R., STILES, I., PERRY, L., and COMBS, S,. 2010. Examining the characteristics of workplace in one non-tertiary hospital. J Clin Nurs. vol.19, pp. 479-488.

CIMETE, G., GENCALP, N.S., and KESKIN, G.,2003. Quality of life and job satisfaction of nurses. J Nurs Care

Qual, vol.18, pp. 151-158.

COVWIN, L., 2002. The effects of nurses job satisfaction on retention: an Australian perspective. J Nurs Admin,vol.32, iss.5, pp. 283-91.

HABAZIN, I., 2013. Povezanost emocionalnih s ponašajnim i fiziološkim odgovoroma na posao medicinskih sestara i tehničara u bolničkim uslovima. Hrvatska revizija za rehabilitaciona istraživanja, vol. 49, iss.1, pp. 37-48.

HASSELHORM, H.M., MULLER, B.H., TACKENBERG, P., and BUESCHER A., 2005. Psychological and physical health among nurses in Europe. NEXT scientific report.University of Wuppertal and University of Witten, Germany, pp. 35-37

ILIOPOULOU, K.K., and WHILE, A.E., 2010. Professional autonomy and job satisfaction: survey of critical care nurses in mainland Greece. J Adv Nurs,vol.66, pp. 2520-2531.

JEZUIT, D., 2003. Personalization as it relates to nursesuffering: how managers can recognize the phenomenon and assist suffering nurses. Jonas Healthc Law Ethics Regul, vol.5, pp. 25-28.

KNEZEVIĆ, B., GOLUBIĆ, R., MILOŠEVIĆ, M., MATEC, L., and MUSTAJBEGOVIĆ, J., 2009. Zdravstveni djelatnici u bolnicama i stres na radu, vol. 51, pp. 85-91.

LIE, J.A., ROESSINK J., and KJAERHEIM, K., 2006. Breast cancer and night work among Norwegian nurses. Cancer Causes Control,vol. 17, iss.1, pp. 39-44.

MILOŠEVIĆ, M., GOLUBIĆ, R., KNEZEVIĆ, B., GOLUBIĆ, K., BUBAS, M., and MUSTAJBEGOVIĆ, J.,2011. Work ability as a major determinant of clin nurs quality of life. J Clin Nurs, vol. 20, pp. 2931-2938.

SHAO, M.F., CHOU, Y.C., YEH, M.Y., and TZENG, W.C.,2010. Sleep quality and quality of life in female shift- working nurses. J Adv Nurs, vol. 66, pp. $1565-1572$.

SPURGEON A., HARRINGTON J.M., and COOPER C.L., 1997. Health andsafety problems associated with long working hours:a review of the current position. Occupational Environmental Medicine, vol. 54, pp. 367-375.

WARE J.E., SNOW K.K., KOSINSKI M., and GENDEK B., 1993. SF-36 Health Survey: Manual and Interpretation Guide. Boston: The Health Institute, New England Medical Center. 
WARE J.E., SNOW K.K., KOSINSKI M., and GENDEK B., 200o. SF-36 Health Survey: Manual and Interpretation Guide. Lincoln, RI: QualityMetric Incorporatd.

WILLIAM, J.S., COHEN, R.D., SHEMA, J.S., and KAPLAN, G.A., 1996. Successful Ageing: Predicators and Associated Activities. American Journal of Epidemiology. pp. 135-141. 